\title{
Molecular Mechanisms of Neonatal Hyperinsulinism
}

\author{
Irina Giurgea ${ }^{a} \quad$ Christine Bellanné-Chantelot $^{b}$ Maria Ribeiro ${ }^{c}$ Laurence Hubert ${ }^{d}$ \\ Christine Sempoux ${ }^{e}$ Jean-Jacques Robert ${ }^{d}$ Oliver Blankenstein ${ }^{f}$ \\ Kahlid Hussaing ${ }^{g}$ Francis Brunelle ${ }^{d}$ Claire Nihoul-Fékétéd Jacques Rahier ${ }^{\mathrm{e}}$ \\ Francis Jaubert $^{d}$ Pascale de Lonlay ${ }^{d}$ \\ a INSERM U654 and Department of Genetics, Hôpital Henri Mondor, Créteil; b Department of Biology, \\ Hôpital Saint-Antoine, Paris; ' ${ }^{C}$ RM 0205 INSERM-CEA, Service Hospitalier Frédéric Joliot, DSV, DRM, Orsay; \\ ${ }^{\mathrm{d} D e p a r t m e n t s ~ o f ~ P e d i a t r i c s, ~ R a d i o l o g y, ~ S u r g e r y ~ a n d ~ P a t h o l o g y, ~ H o ̂ p i t a l ~ N e c k e r-E n f a n t s ~ M a l a d e s, ~ P a r i s, ~ F r a n c e ; ~}$ \\ e Department of Pathology, Cliniques universitaires Saint-Luc, Université Catholique de Louvain, Brussels, Belgium; \\ ${ }^{f}$ Departments of Pediatrics, Humboldt-Universität zu Berlin, and Charité CVK OHC Kinderklinik, Berlin, Germany; \\ and 9 Departments of Pediatrics, Great Ormond Street Children's Hospital NHS Trust and Institute of Child Health, \\ London, UK
}

\section{Key Words}

Neonatal hyperinsulinism, molecular mechanisms •

Hypoglycaemia • Diffuse insulin hypersecretion •

Focal adenomatous hyperplasia

\begin{abstract}
Congenital hyperinsulinism (CHI), characterized by profound hypoglycaemia related to inappropriate insulin secretion, may be associated histologically with either diffuse insulin hypersecretion or focal adenomatous hyperplasia, which share a similar clinical presentation, but result from different molecular mechanisms. Whereas diffuse $\mathrm{CHI}$ is of autosomal recessive, or less frequently of autosomal dominant, inheritance, focal $\mathrm{CHI}$ is sporadic. The most common mechanism underlying $\mathrm{CHI}$ is dysfunction of the pancreatic ATP-sensitive potassium channel $\left(\mathrm{K}^{+}{ }_{\text {ATP }}\right)$. The two subunits of the $\mathrm{K}^{+}{ }_{\text {ATP }}$ channel are encoded by the sulfonylurea receptor gene (SUR1 or $A B C C 8$ ) and the inward-rectifying potassium channel gene (KIR6.2 or KCNJ11), both located in the 11p15.1 region. Germ-line, paternally inherited, mutations of the
\end{abstract}

SUR1 or KIR6.2 genes, together with somatic maternal haploinsufficiency for $11 \mathrm{p} 15.5$, were shown to result in focal $\mathrm{CHI}$. Diffuse $\mathrm{CHI}$ results from germ-line mutations in the SUR1 or KIR6.2 genes, but also from mutations in several other genes, namely glutamate dehydrogenase (with associated hyperammonaemia), glucokinase, short-chain L-3-hydroxyacyl$\mathrm{CoA}$ dehydrogenase, and insulin receptor gene. Hyperinsulinaemic hypoglycaemia may be observed in several overlapping syndromes, such as Beckwith-Wiedemann syndrome (BWS), Perlman syndrome, and, more rarely, Sotos syndrome. Mosaic genome-wide paternal isodisomy has recently been reported in patients with clinical signs of BWS and $\mathrm{CHI}$. The primary causes of $\mathrm{CHI}$ are genetically heterogeneous and have not yet been completely unveiled. However, secondary causes of hyperinsulinism have to be considered such as fatty acid oxidation deficiency, congenital disorders of glycosylation and factitious hypoglycaemia secondary to Munchausen by proxy syndrome.

Copyright $\odot 2006$ S. Karger AG, Basel

Dr. Irina Giurgea

INSERM U654 and Department of Genetics, Hôpital Henri Mondor

51, avenue du mal de Lattre de Tassigny

FR-94010 Créteil Cedex (France)

Tel. +33 14981 6871, Fax +33 14981 2842, E-Mail giurgea@im3.inserm.fr 


\section{Introduction}

Congenital hyperinsulinism (CHI, MIM 256450) related to inappropriate insulin secretion is the most common cause of hypoglycaemia in newborns and infants. Hypoglycaemia revealed by seizures in about half of the cases is often severe with secondary brain damage [1-4]. Although the clinical presentation of hyperinsulinism is similar, it may result from different molecular causes [5-10].

The diagnostic criteria for $\mathrm{CHI}$ include recurrent fasting and fed hypoglycaemia $(<3 \mathrm{mmol} / \mathrm{l})$ with inadequate insulin plasma levels requiring high rates of intravenous (IV) glucose ( $>10 \mathrm{mg} / \mathrm{kg} / \mathrm{min})$ and increased plasma glucose after IV glucagon injection. In the absence of clearly abnormal insulin levels during the hypoglycaemic episode, a 4- to 6-hour fasting test in search of inappropriately low plasma levels of ketone bodies, free fatty acids, and branched chain amino acids, may be helpful. Mild hepatomegaly is common and does not prevent the diagnosis of hyperinsulinism. Facial dysmorphism with high forehead, large and bulbous nose with short columella, smooth philtrum and thin upper lip is frequently observed in all types of hyperinsulinism [11]. Epilepsy seems to be frequent in patients with hyperinsulinism associated to hyperammonaemia and is not explained by hypoglycaemia only [12]. However, mostly, hypoglycaemia is the only symptom.

The onset of hypoglycaemia is reported to occur in the neonate or after the first month of life [13-15]. In the neonatal period, hypoglycaemia is severe (often $<1 \mathrm{mmol} / \mathrm{l}$ ) and occurs within the first $72 \mathrm{~h}$ of life. The majority of affected newborns with severe $\mathrm{CHI}$ are macrosomic at birth. Other symptoms are: abnormal movements, tremulousness, hypotonia, cyanosis, or hypothermia. In some cases, hypoglycaemia is discovered by routine measurement of blood glucose. CHI patients presenting with hypoglycaemia later in infancy (1-12 months of age) have a similar clinical presentation, but usually require lower rates of IV glucose to maintain glycaemia within normal ranges.

CHI may be associated histologically with two major forms: diffuse insulin hypersecretion or focal adenomatous hyperplasia. Both forms share a similar clinical presentation. Histologically, focal adenomatous hyperplasia is a small poorly delineated lesion composed of normally structured hyperplastic islets ( $\beta$ cells surrounded by non$\beta$ cells), separated by few exocrine acini, thus maintaining a normal lobular pancreatic architecture [16]. A high proliferation rate of $\beta$ cells was shown inside the lesion, whereas in the normal adjacent pancreas, small resting islets, made of packed endocrine cells with scanty cytoplasm, exhibit no sign of proliferation [2]. Furthermore, loss of the maternally expressed CDKN1C gene within the lesion is evidenced by the absence of immunohistochemical staining of the corresponding protein, in contrast to normal surrounding islets $[16,17]$. These features differ from true adult-type pancreatic adenoma or insulinoma which are microscopically less well distinguished from adjacent pancreatic tissue, sometimes extending between exocrine acini or including normal islets. Outside insulinomas, islets show regular nuclei and normally abundant cytoplasm and are thus very different from those located in non-lesional pancreas of focal forms [16, 17]. Diffuse hyperinsulinism is characterized histologically by the presence of $\beta$ cells with a particularly abundant cytoplasm and a large nucleus in the islets throughout the whole pancreas [18-21]. These features are interpreted as a morphological evidence for the continuous hyperfunction of $\beta$ cells $[18,19,22]$.

Clinical features and preoperative classical radiology of the pancreas, including sonography, CT scan and MRI, cannot discriminate between focal and diffuse disease. Therefore, pancreatic venous sampling and pancreatic arterial calcium stimulation were, until recently, the only preoperative procedures available for localizing the site of insulin secretion [23, 24]. Pancreatic venous sampling allows to collect venous blood samples from the entire pancreas (head, isthmus, body and tail) for measurements of plasma glucose, insulin and C-peptide levels [23]. Patients with a focal lesion have high plasma insulin and C-peptide levels in one or more consequent samples, and low plasma insulin and C-peptide levels in the remaining pancreatic samples. By contrast, patients with diffuse hyperinsulinism have high plasma insulin and C-peptide levels in all pancreatic samples [23, 24]. A new accurate non-invasive technique, $\left[{ }^{18} \mathrm{~F}\right]$-fluoro-Ldopa whole-body PET, has only recently become available to detect hyperfunctional pancreatic islets. Abnormal focal uptake of $\left[{ }^{18} \mathrm{~F}\right]$-fluoro-L-dopa is observed in the pancreas of patients with a focal lesion, while a diffuse uptake of the radiotracer is observed over the whole pancreas for patients with diffuse insulin secretion [25, 26]. PET scanning with ${ }^{18} \mathrm{~F}$-dopa is to date the most employed method to distinguish between focal and diffuse CHI.

The treatment of hyperinsulinemic hypoglycaemia must be rapid and aggressive in order to prevent irreversible brain damage. In neonates, this often necessitates central venous access and continuous oral feeding using 
Fig. 1. Decision tree for clinical management of patients with CHI. Hyperammonaemia is found in $\mathrm{HA} / \mathrm{HI}$ syndrome. Methylation abnormalities at 11 p 15 region can be found in syndromic forms of hyperinsulinism, namely in BWS. Secondary causes of hyperinsulinism such as fatty acid oxidation defects detected by acylcarnitine profile, and congenital disorders of glycosylation detected by transferrin glycosylation studies have to been excluded. $\mathrm{NH}_{3}=$ Ammonaemia; acylcarn. = acylcarnitine profile; transferrin $=$ transferrin glycosylation; meth. $11 \mathrm{p} 15=$ detection of methylation abnormalities at $11 \mathrm{p} 15$ region; dom. = autosomal dominant inheritance.

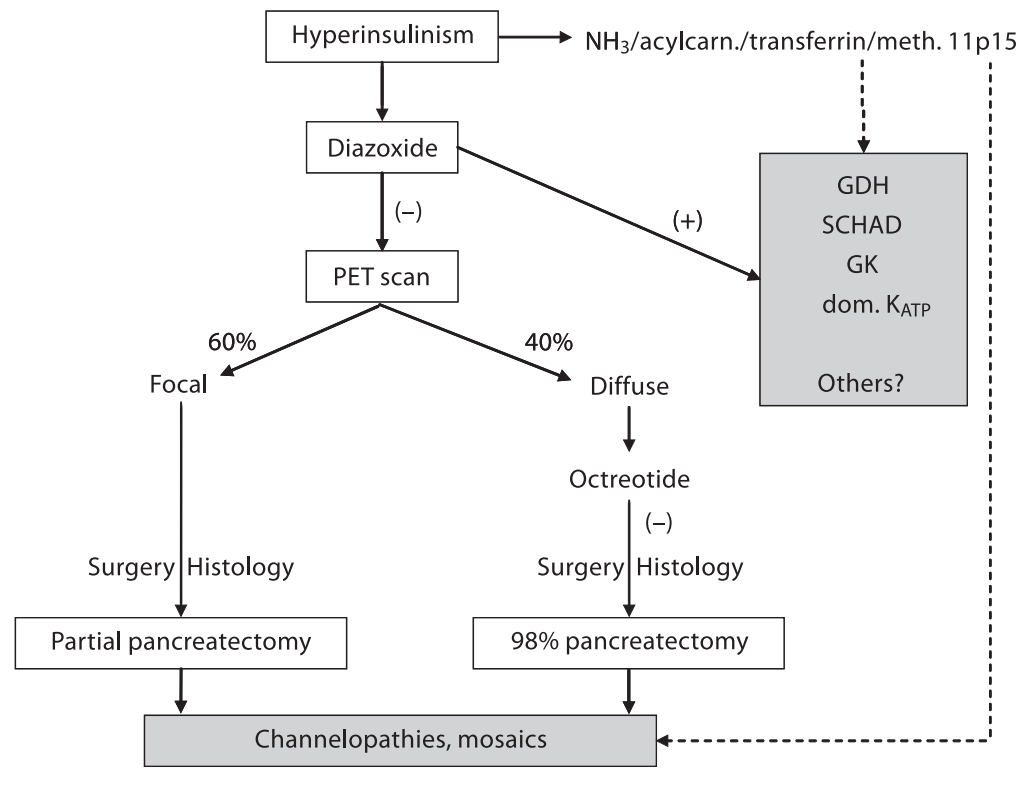

Secondary causes of hyperinsulinism should also be excluded, namely fatty acid oxidation defects (acylcarnitine profile), congenital disorders of glycosylation (transferrin glycosylation), and Munchausen syndrome by proxy [28], as the treatment will be different. Figure 1 contains a decision tree that may be useful for the clinical management of patients with CHI.

Patients resistant to medical treatment require pancreatectomy: focal CHI can be definitively cured by a limited pancreatectomy, while diffuse $\mathrm{CHI}$ requires a subtotal pancreatectomy, with a high risk of secondary diabetes mellitus. Intraoperative histological analysis is performed to provide confirmation of the findings of pancreatic catheterization or PET scanning and to guide the limits of pancreatic resection, in patients suspected of focal CHI.

\section{Molecular Basis}

The most common mechanism underlying $\mathrm{CHI}$ is dysfunction of the pancreatic ATP-sensitive potassium channel $\left(\mathrm{K}^{+}{ }_{\text {ATP }}\right)$. The two subunits of the $\mathrm{K}^{+}{ }_{\text {ATP }}$ channel are encoded by the sulfonylurea receptor gene (SUR1 or 
$A B C C 8)$ and the inward-rectifying potassium channel gene (KIR6.2. or KCNJ11), both located in the 11p15.1 region. $\mathrm{K}_{\text {ATP }}^{+}$channels are open in unstimulated $\beta$ cells, establishing a resting membrane potential of $-65 \mathrm{mV}$. At this state, the intracellular ATP/ADP ratio is low (ATP $1 \mathrm{mmol} / \mathrm{l}$, ADP $40 \mathrm{mmol} / \mathrm{l}$ ), keeping the channels, which have a high sensitivity to ADP, open. Following glucose uptake and metabolism, ATP/ADP increases, ADP concentration decreases, and leads to closing of $\mathrm{K}^{+}{ }_{\text {ATP }}$ channels and depolarization of the cell membrane. This opens the voltage-gated $\mathrm{Ca}^{2+}$ channels, allows the influx of extracellular calcium, and the exocytosis of insulin. CHI 'channelopathies' are due to inhibiting SUR1 or KIR6.2 mutations. These mutations can lead to type 1 channelopathy without channel activity, or to type 2 channelopathy with a decreased channel activity due either to defective function, or to decreased number of channels. Heterogeneous outcome is observed for the same mutation as some cells manifest a type 1 channelopathy, others a type 2 channelopathy, and other mutated cells have a normal activity of the potassium channel $[29,30]$. This observation could be explained by interactions with modulator genes, exogenous factors, or variable degree of penetrance of the mutation.

Mutations of SUR1 gene are responsible for $50-60 \%$ of $\mathrm{CHI}$, whatever focal or diffuse CHI, especially in neonates. More than 100 distinct mutations, distributed throughout the SUR1 gene, have already been described [31-34]. Mutations of KIR6.2 gene are less frequent and are responsible for $10-15 \%$ of $\mathrm{CHI}$.

Less frequent mechanisms of $\mathrm{CHI}$, observed especially in infants, and responsible for diffuse CHI, the 'metabolopathies', are due to enzyme deficiencies of glutamate dehydrogenase (GDH), glucokinase (GK), shortchain L-3-hydroxyacyl-CoA dehydrogenase (SCHAD) or to insulin receptor dysfunctions (fig. 2). In contrast to patients with 'channelopathies', those with 'metabolic' $\mathrm{CHI}$ are sensitive to diazoxide (which acts on the potassium channel), as $\mathrm{K}_{\text {ATP }}^{+}$channels are functional in these patients.

\section{Modes of Inheritance}

\section{Sporadic Forms}

Recent estimates from France, Japan and the United States suggest that $40-65 \%$ of all CHI patients have a focal form $[31,35,36]$.

Focal CHI has been shown to result from a paternally inherited mutation in the SUR1 or KIR6.2 genes and loss of the maternal 11p15 allele (loss of heterozygosity, $\mathrm{LOH})$. $\mathrm{LOH}$ is a somatic event restricted to the pancreatic lesion which leads to tumour inception through disruption of the balance of expression of several imprinted genes located in the 11p15.5 region and controlling cell growth [37]. Because of the somatic character of $\mathrm{LOH}$, focal $\mathrm{CHI}$ is a sporadic event. In patients with focal CHI, the pancreas lesion is generally unique with a size of $<10 \mathrm{~mm}$ in the largest aspect [16, 18-20, 38-40]. Rarely, patients with multiple-focal lesions or giant lesions have been reported [38]. The underling molecular mechanism of these forms is similar to the one described in the small solitary forms but the onset during the pancreas embryogenesis may be different: earlier for the giant forms and multiple-hit for the multiple-focal forms [41].

Patients with de novo germ-line mutations in genes responsible for diffuse forms of CHI may be considered initially as sporadic cases.

\section{Autosomal Recessive Inheritance}

In the autosomal recessive form, the most frequently involved genes are SUR1 [6] or KIR6.2 [7, 42] and, less commonly, the short-chain L-3-hydroxyacyl-CoA dehydrogenase $(S C H A D)$ gene [10].

\section{Autosomal Dominant Inheritance}

The second most common form of $\mathrm{CHI}$ involving the GLUD1 gene, coding for GDH, is often associated with hyperammonaemia (HI/HA syndrome) [43]. Dominantly expressed missense mutations of GLUD1 gene result in a gain of function of GDH, a mitochondrial matrix enzyme. This induces an increase of the oxidative deamination of glutamate in $\alpha$-ketoglutarate and ammonium, responsible for an increased Krebs cycle activity, which results in an increased ATP/ADP ratio, and consequently activation of $\mathrm{K}^{+}$ATP channel with subsequent cell depolarization and insulin release [9].

Dominantly expressed GK mutations are a rare cause of $\mathrm{CHI}$ [8]. They result in a gain of function by increased affinity of GK for glucose leading to inappropriate insulin secretion. These mutations are remote from the glucose-binding site and suggest an allosteric regulation defect.

Less frequently than in the recessive (diffuse $\mathrm{CHI}$ ) or sporadic (focal CHI) form, SUR1 gene can also be involved in dominant CHI. In this case, the histological lesion is diffuse.

The insulin receptor (INSR) gene was recently implicated in a dominant form of hyperinsulinemic hypogly- 


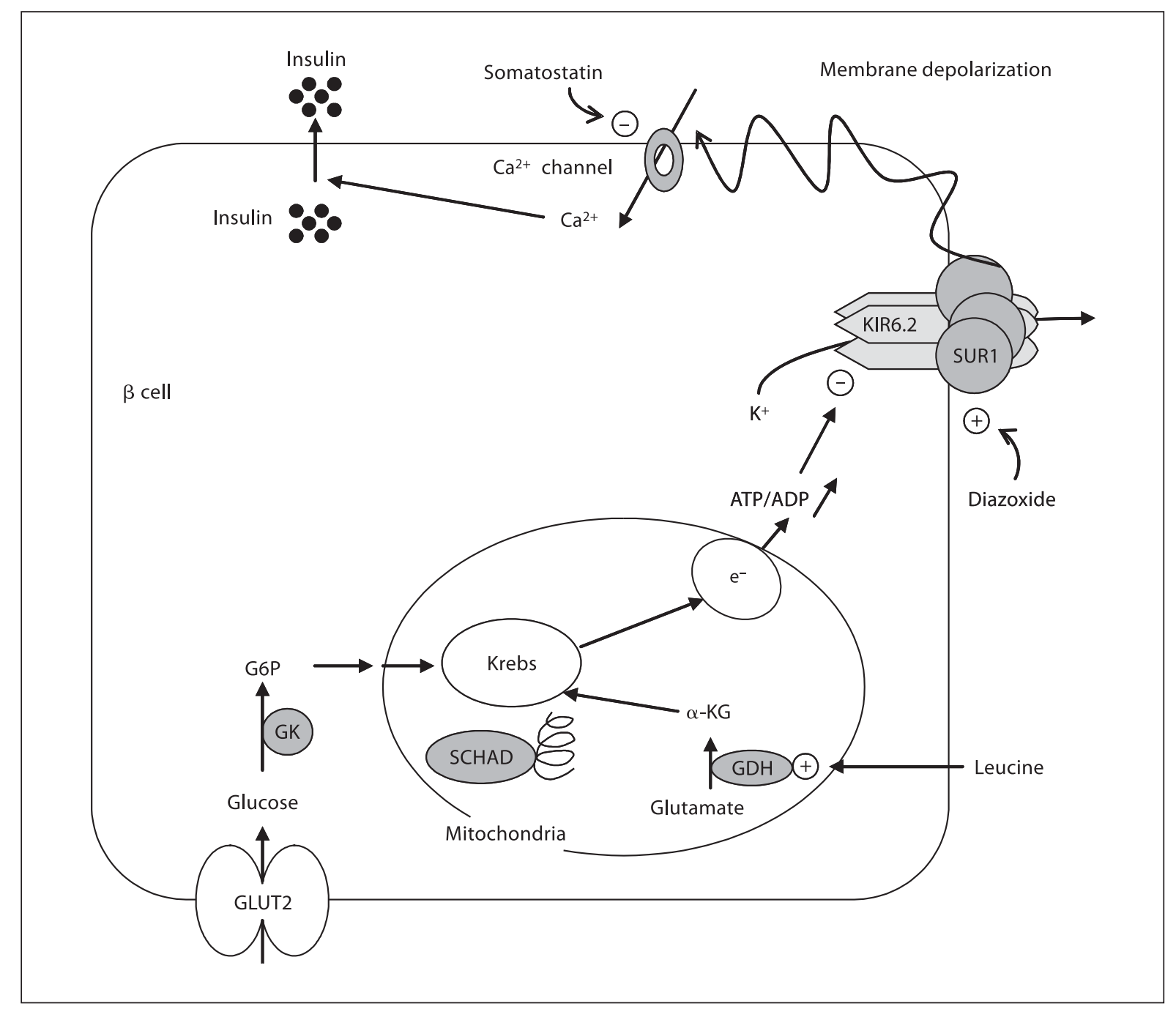

Fig. 2. Schematic representation of the regulation of insulin secretion by glucose in pancreatic $\beta$ cells. GLUT2 catalyses glucose uptake by $\beta$ cells. The phosphorylation of glucose to glucose- 6 phosphate by glucokinase initiates $\beta$-cell glucose metabolism. Leucine, one of the most potent amino acids in stimulating insulin secretion, acts indirectly as a positive allosteric effector of glutamate dehydrogenase increasing the rate of oxidation of glutamate to $\alpha$-ketoglutarate. Both glucose and leucine interact with the Krebs cycle activity resulting in ATP synthesis. This increase of the ATP/ADP ratio triggers the closure of the potassium chan- nel, leading to depolarization of the cell membrane, influx of extracellular calcium, and release of insulin from storage granules. The several pathways involved in insulin secretion explain the modality of effectiveness of medical cures such as diazoxide, somatostatin, and protein-restricted diet. GLUT2 = Glucose transporter 2; G6P = glucose-6-phosphate; GK = glucokinase; GDH = glutamate dehydrogenase; $\alpha-\mathrm{KG}=\alpha$-ketoglutarate; Krebs $=$ Krebs cycle; $\mathrm{e}^{-}=$mitochondrial respiratory chain; SUR1 = sulfonylurea receptor; KIR6.2 = inward-rectifying potassium channel are the subunits of potassium channel. caemia [44]. Patients presented with postprandial as well as fasting hyperinsulinemic hypoglycaemia associated with resistance to insulin [44].

Exercise-induced hyperinsulinism is a novel, autosomal dominant form of $\mathrm{CHI}$, which has been identified in two families. The patients suffer from hypoglycaemic symptoms only when performing strenuous physical ex- ercise [45]. The underlying mechanism of hypoglycaemia is unknown, so far.

\section{Syndromic Forms}

Finally, hyperinsulinemic hypoglycaemia can be 'syndromic' as observed in several overlapping syndromes, such as Beckwith-Wiedemann syndrome (BWS) [46], 
Table 1. Genetic mechanisms of congenital hyperinsulinism

\begin{tabular}{lll}
\hline $\begin{array}{l}\text { Mode of } \\
\text { inheritance }\end{array}$ & $\begin{array}{l}\text { Histological } \\
\text { form }\end{array}$ & $\begin{array}{l}\text { Genetic mechanism } \\
\text { or the involved gene }\end{array}$ \\
\hline Sporadic & Focal & $\begin{array}{l}\text { Paternal inherited SUR1 } \\
\text { or KIR6.2 mutation }+ \\
\text { loss of the 11p15 maternal } \\
\text { allele in the pancreatic lesion } \\
\text { de novo mutation }\end{array}$ \\
\hline $\begin{array}{ll}\text { Autosomal } \\
\text { recessive }\end{array}$ & Diffuse & SUR1 \\
& KIR6.2 \\
$\begin{array}{l}\text { Autosomal } \\
\text { dominant }\end{array}$ & Diffuse & SUHAD \\
& Other & KIR6.2 \\
& & GLUD1 \\
& & INK \\
\hline Syndromic & Diffuse & Mosaics \\
forms & Other & Unknown \\
\hline
\end{tabular}

Perlman syndrome [47] and, more rarely, in Sotos syndrome [48]. BWS results from several identified genetic and epigenetic molecular events including paternal isodisomy [49], abnormal methylation of IGF2/H19 [50], chro- mosomal aberrations involving the 11 p15 region [51], and CDKN1C mutation [52]. Hypoglycaemia in BWS patients has been associated with paternal uniparental disomy of 11 15 rather than other genetic abnormalities [46], but the pathophysiological mechanism leading to hyperinsulinic hypoglycaemia is still unclear as no evidence for duplication of INS, HRAS1 and IGF2 [53] or overexpression of the INS and IGF2 genes [54] was found. A case of BWS with $\mathrm{CHI}$ and mosaic genome-wide paternal isodisomy has been reported [55], and we may suggest that mosaic and genome-wide paternal isodisomy are likely to be underdiagnosed in patients with clinical signs of BWS or CHI.

The genetic mechanism of $\mathrm{CHI}$ and the most frequent modes of inheritance are summarized in table 1.

\section{Conclusion}

$\mathrm{CHI}$ involves widely heterogeneous genes and mechanisms. Other genes encoding transcription factors as well as genes implicated in $\beta$-cell metabolism are probably involved. Furthermore, CHI association with disorders known to be related to imprinted regions of the human genome should be the focus of further in-depth diagnostic efforts.

\section{References}

- Pagliara AS, Karl IE, Haymond M, Kipnis DM: Hypoglycemia in infancy and childhood. I. J Pediatr 1973;82:365-379.

$\checkmark 2$ Thomas CG Jr, Underwood LE, Carney CN, Dolcourt JL, Whitt JJ: Neonatal and infantile hypoglycemia due to insulin excess: new aspects of diagnosis and surgical management. Ann Surg 1977;185:505-517.

3 Cornblath M, Schwartz R, Aynsley-Green A, Lloyd JK: Hypoglycemia in infancy: the need for a rational definition. A Ciba Foundation discussion meeting. Pediatrics 1990;85:834837.

4 Aynsley-Green A, Hussain K, Hall J, Saudubray JM, Nihoul-Fekete C, De Lonlay-Debeney P, Brunelle F, Otonkoski T, Thornton P, Lindley KJ: Practical management of hyperinsulinism in infancy. Arch Dis Child Fetal Neonatal Ed 2000;82:F98-F107.

5 De Lonlay-Debeney P, Poggi-Travert F, Fournet JC, Sempoux C, Vici CD, Brunelle F, Touati G, Rahier J, Junien C, Nihoul-Fekete C, Robert JJ, Saudubray JM: Clinical features of 52 neonates with hyperinsulinism. N Engl J Med 1999;340:1169-1175.
Nestorowicz A, Wilson BA, Schoor KP, Inoue H, Glaser B, Landau H, Stanley CA, Thornton PS, Clement JP, Bryan J, AguilarBryan L, Permutt MA: Mutations in the sulfonylurea receptor gene are associated with familial hyperinsulinism in Ashkenazi Jews. Hum Mol Genet 1996;5:1813-1822.

-7 Thomas PM, Cote GJ, Wohllk N, Mathew PM, Gagel RF: The molecular basis for familial persistent hyperinsulinemic hypoglycemia of infancy. Proc Assoc Am Physicians 1996;108:14-19.

-8 Glaser B, Kesavan P, Heyman M, Davis E, Cuesta A, Buchs A, Stanley CA, Thornton PS, Permutt MA, Matschinsky FM, Herold KC: Familial hyperinsulinism caused by an activating glucokinase mutation. N Engl J Med 1998;338:226-230.

-9 Stanley CA, Lieu YK, Hsu BY, Burlina AB, Greenberg CR, Hopwood NJ, Perlman K, Rich BH, Zammarchi E, Poncz M: Hyperinsulinism and hyperammonaemia in infants with regulatory mutations of the glutamate dehydrogenase gene. N Engl J Med 1998;338: 1352-1357.
10 Clayton PT, Eaton S, Aynsley-Green A, Edginton M, Hussain K, Krywawych S, Datta V, Malingre HE, Berger R, van den Berg IE: Hyperinsulinism in short-chain L-3-hydroxyacyl-CoA dehydrogenase deficiency reveals the importance of $\beta$-oxidation in insulin secretion. J Clin Invest 2001;108:457-465.

11 De Lonlay P, Cormier-Daire V, Amiel J, TouatiG, Goldenberg A, Fournet JC, Brunelle F, Nihoul-Fekete C, Rahier J, Junien C, Robert JJ, Saudubray JM: Facial appearance in persistent hyperinsulinemic hypoglycemia. Am J Med Genet 2002;111:130-133.

12 Raizen DM, Brooks-Kayal A, Steinkrauss L, Tennekoon GI, Stanley CA, Kelly A: Central nervous system hyperexcitability associated with glutamate dehydrogenase gain of function mutations. J Pediatr 2005;146:388-394.

13 Filler RM, Weinberg MJ, Cutz E, Wesson DE, Ehrlich RM: Current status of pancreatectomy for persistent idiopathic neonatal hypoglycemia due to islet cell dysplasia. Prog Pediatr Surg 1991;26:60-75. 
14 De Lonlay P, Fournet JC, Touati G, Groos MS, Martin D, Sevin C, Delagne V, Mayaud C, Chigot V, Sempoux C, Brusset MC, Laborde K, Bellane-Chantelot C, Vassault A, Rahier J, Junien C, Brunelle F, Nihoul-Fekete C, Saudubray JM, Robert JJ: Heterogeneity of persistent hyperinsulinaemic hypoglycaemia. A series of 175 cases. Eur J Pediatr 2002; 161:37-48.

$\checkmark 15$ Meissner T, Mayatepek E: Clinical and genetic heterogeneity in congenital hyperinsulinism. Eur J Pediatr 2002;161:6-20.

$\checkmark 16$ Kloppel G, Reinecke-Luthge A, Koschoreck $F$ : Focal and diffuse $\beta$-cell changes in persistent hyperinsulinemic hypoglycemia of infancy. Endocr Pathol 1999;10:299-304.

-17 Sempoux C, Guiot Y, Dahan K, Moulin P, Stevens M, Lambot V, de Lonlay P, Fournet JC, Junien C, Jaubert F, Nihoul-Fekete C, Saudubray JM, Rahier J: The focal form of persistent hyperinsulinemic hypoglycemia of infancy: morphological and molecular studies show structural and functional differences with insulinoma. Diabetes 2003;52: 784-794.

18 Jaffe R, Hashida Y, Yunis EJ: Pancreatic pathology in hyperinsulinemic hypoglycemia of infancy. Lab Invest 1980;42:356-365.

-19 Rahier J, Falt K, Muntefering H, Becker K, Gepts W, Falkmer S: The basic structural lesion of persistent neonatal hypoglycaemia with hyperinsulinism: deficiency of pancreatic D cells or hyperactivity of B cells? Diabetologia 1984;26:282-289.

20 Sempoux C, Guiot Y, Lefevre A, NihoulFekete C, Jaubert F, Saudubray JM, Rahier J: Neonatal hyperinsulinemic hypoglycemia: heterogeneity of the syndrome and keys for differential diagnosis. J Clin Endocrinol Metab 1998;83:1455-1461.

-21 Rahier J, Sempoux C, Fournet JC, Poggi F, Brunelle F, Nihoul-Fekete C, Saudubray JM, Jaubert F: Partial or near-total pancreatectomy for persistent neonatal hyperinsulinaemic hypoglycaemia: the pathologist's role. Histopathology 1998;32:15-19.

$\checkmark 22$ Sempoux C, Poggi F, Brunelle F, Saudubray JM, Fekete C, Rahier J: Nesidioblastosis and persistent neonatal hyperinsulinism. Diabete Metab 1995;21:402-407.

$\checkmark 23$ Brunelle F, Negre V, Barth MO, Fekete CN, Czernichow P, Saudubray JM, Kuntz F, Tach T, Lallemand D: Pancreatic venous samplings in infants and children with primary hyperinsulinism. Pediatr Radiol 1989;19: 100-103.

$\checkmark 24$ Chigot V, De Lonlay P, Nassogne MC, Laborde K, Delagne V, Fournet JC, NihoulFekete C, Saudubray JM, Brunelle F: Pancreatic arterial calcium stimulation in the diagnosis and localisation of persistent hyperinsulinemic hypoglycaemia of infancy. Pediatr Radiol 2001;31:650-655.
25 Ribeiro MJ, De Lonlay P, Delzescaux T, Boddaert N, Jaubert F, Bourgeois S, Dolle F, Nihoul-Fekete C, Syrota A, Brunelle F: Characterization of hyperinsulinism in infancy assessed with PET and ${ }^{18} \mathrm{~F}$-fluoro-L-dopa. J Nucl Med 2005;46:560-566.

26 Otonkoski T, Nanto-Salonen K, Seppanen M, Veijola R, Huopio H, Hussain K, Tapanainen P, Eskola O, Parkkola R, Ekstrom K, Guiot Y, Rahier J, Laakso M, Rintala R, Nuutila P, Minn H: Noninvasive diagnosis of focal hyperinsulinism of infancy with $\left[{ }^{18} \mathrm{~F}\right]$-dopa positron emission tomography. Diabetes 2006;55:13-18.

27 Touati G, Poggi-Travert F, Ogier de Baulny $\mathrm{H}$, Rahier J, Brunelle F, Nihoul-Fekete C, Czernichow P, Saudubray JM: Long-term treatment of persistent hyperinsulinaemic hypoglycaemia of infancy with diazoxide: a retrospective review of 77 cases and analysis of efficacy-predicting criteria. Eur J Pediatr 1998;157:628-633.

28 Giurgea I, Ulinski T, Touati G, Sempoux C, Mochel F, Brunelle F, Saudubray JM, Fekete C, de Lonlay P: Factitious hyperinsulinism leading to pancreatectomy: severe forms of Munchausen syndrome by proxy. Pediatrics 2005;116:e145-e148.

29 Straub SG, Cosgrove KE, Ammala C, Shepherd RM, O’Brien RE, Barnes PD, Kuchinski N, Chapman JC, Schaeppi M, Glaser B, Lindley KJ, Sharp GW, Aynsley-Green A, Dunne MJ: Hyperinsulinism of infancy: the regulated release of insulin by KATP channel-independent pathways. Diabetes 2001;50:329_ 339.

30 Cosgrove KE, Antoine MH, Lee AT, Barnes PD, de Tullio P, Clayton P, McCloy R, De Lonlay P, Nihoul-Fekete C, Robert JJ, Saudubray JM, Rahier J, Lindley KJ, Hussain K, Aynsley-Green A, Pirotte B, Lebrun P, Dunne MJ: BPDZ 154 activates adenosine 5'-triphosphate-sensitive potassium channels: in vitro studies using rodent insulin-secreting cells and islets isolated from patients with hyperinsulinism. J Clin Endocrinol Metab 2002;87:4860-4868.

31 Glaser B, Thornton P, Otonkoski T, Junien C: Genetics of neonatal hyperinsulinism. Arch Dis Child Fetal Neonatal Ed 2000;82:F79_ F86.

32 Dunne MJ, Cosgrove KE, Shepherd RM, Aynsley-Green A, Lindley KJ: Hyperinsulinism in infancy: from basic science to clinical disease. Physiol Rev 2004;84:239-275.

33 Gloyn AL, Siddiqui J, Ellard S: Mutations in the genes encoding the pancreatic $\beta$-cell KATP channel subunits Kir6.2 (KCNJ11) and SUR1 (ABCC8) in diabetes mellitus and hyperinsulinism. Hum Mutat 2006;27:220 231.

-34 Fernandez-Marmiesse A, Salas A, Vega A, Fernandez-Lorenzo JR, Barreiro J, Carracedo A: Mutation spectra of ABCC8 gene in Spanish patients with hyperinsulinism of infancy (HI). Hum Mutat 2006;27:214.
35 Tanizawa Y, Matsuda K, Matsuo M, Ohta Y, Ochi N, Adachi M, Koga M, Mizuno S, Kajita M, Tanaka Y, Tachibana K, Inoue $H$, Furukawa S, Amachi T, Ueda K, Oka Y: Genetic analysis of Japanese patients with persistent hyperinsulinemic hypoglycemia of infancy: nucleotide-binding fold-2 mutation impairs cooperative binding of adenine nucleotides to sulfonylurea receptor 1 . Diabetes 2000;49:114-120.

36 Stanley CA: Advances in diagnosis and treatment of hyperinsulinism in infants and children. J Clin Endocrinol Metab 2002;87: 4857-4859.

-37 Fournet JC, Mayaud C, de Lonlay P, GrossMorand MS, Verkarre V, Castanet M, Devillers M, Rahier J, Brunelle F, Robert JJ, Nihoul-Fekete C, Saudubray JM, Junien C: Unbalanced expression of 11 p15 imprinted genes in focal forms of congenital hyperinsulinism: association with a reduction to homozygosity of a mutation in ABCC8 or KCNJ11. Am J Pathol 2001;158:2177-2184.

38 Goossens A, Gepts W, Saudubray JM, Bonnefont JP, Nihoul F, Heitz PU, Kloppel G: Diffuse and focal nesidioblastosis. A clinicopathological study of 24 patients with persistent neonatal hyperinsulinemic hypoglycemia. Am J Surg Pathol 1989;13:766-775.

39 Rahier J, Guiot Y, Sempoux C: Persistent hyperinsulinaemic hypoglycaemia of infancy: a heterogeneous syndrome unrelated to nesidioblastosis. Arch Dis Child Fetal Neonatal Ed 2000;82:F108-F112.

40 Sempoux C, Guiot Y, Rahier J: The focal form of persistent hyperinsulinemic hypoglycemia of infancy. Diabetes 2001;50 (suppl 1):S182-S183.

41 Giurgea I, Sempoux C, Bellanne-Chantelot C, Ribeiro M, Hubert L, Boddaert N, Saudubray JM, Robert JJ, Brunelle F, Rahier J, Jaubert F, Nihoul-Fekete C, de Lonlay P: The Knudson's two-hit model and timing of somatic mutation may account for the phenotypic diversity of focal congenital hyperinsulinism. J Clin Endocrinol Metab 2006, Aug 1 [Epub ahead of print].

42 Nestorowicz A, Inagaki N, Gonoi T, Schoor KP, Wilson BA, Glaser B, Landau H, Stanley CA, Thornton PS, Seino S, Permutt MA: A nonsense mutation in the inward rectifier potassium channel gene, Kir6.2, is associated with familial hyperinsulinism. Diabetes 1997;46:1743-1748.

43 Stanley CA, Fang J, Kutyna K, Hsu BY, Ming JE, Glaser B, Poncz M: Molecular basis and characterization of the hyperinsulinism/hyperammonaemia syndrome: predominance of mutations in exons 11 and 12 of the glutamate dehydrogenase gene. HI/HA contributing investigators. Diabetes 2000;49:667-673.

44 Hojlund K, Hansen T, Lajer M, Henriksen JE, Levin K, Lindholm J, Pedersen O, BeckNielsen H: A novel syndrome of autosomaldominant hyperinsulinemic hypoglycemia linked to a mutation in the human insulin receptor gene. Diabetes 2004;53:1592-1598. 
45 Otonkoski T, Kaminen N, Ustinov J, Lapatto R, Meissner T, Mayatepek E, Kere J, Sipila I: Physical exercise-induced hyperinsulinemic hypoglycemia is an autosomal-dominant trait characterized by abnormal pyruvateinduced insulin release. Diabetes 2003;52: 199-204.

-46 DeBaun MR, Niemitz EL, McNeil DE, Brandenburg SA, Lee MP, Feinberg AP: Epigenetic alterations of H19 and LIT1 distinguish patients with Beckwith-Wiedemann syndrome with cancer and birth defects. Am J Hum Genet 2002;70:604-611.

-47 Henneveld HT, van Lingen RA, Hamel BC, Stolte-Dijkstra I, van Essen AJ: Perlman syndrome: four additional cases and review. Am J Med Genet 1999;86:439-446.

-48 Baujat G, Rio M, Rossignol S, Sanlaville D, Lyonnet S, Le Merrer M, Munnich A, Gicquel C, Cormier-Daire V, Colleaux L: Paradoxical NSD1 mutations in Beckwith-Wiedemann syndrome and 11p15 anomalies in Sotos syndrome. Am J Hum Genet 2004;74: 715-720.
49 Henry I, Bonaiti-Pellie C, Chehensse V, Beldjord C, Schwartz C, Utermann G, Junien C: Uniparental paternal disomy in a genetic cancer-predisposing syndrome. Nature 1991;351:665-667.

50 Weksberg R, Shen DR, Fei YL, Song QL, Squire J: Disruption of insulin-like growth factor 2 imprinting in Beckwith-Wiedemann syndrome. Nat Genet 1993;5:143150.

51 Okano Y, Osasa Y, Yamamoto H, Hase Y, Tsuruhara T, Fujita H: An infant with Beckwith-Wiedemann syndrome and chromosomal duplication 11p13-pter: correlation of symptoms between 11p trisomy and Beckwith-Wiedemann syndrome. Jinrui Idengaku Zasshi 1986;31:365-372.

52 Hatada I, Ohashi H, Fukushima Y, Kaneko Y, Inoue M, Komoto Y, Okada A, Ohishi S, Nabetani A, Morisaki H, Nakayama M, Niikawa N, Mukai T: An imprinted gene p57KIP2 is mutated in Beckwith-Wiedemann syndrome. Nat Genet 1996;14:171173.
53 Henry I, Jeanpierre M, Barichard F, Serre JL, Mallet J, Turleau C, de Grouchy J, Junien C: Duplication of HRAS1, INS, and IGF2 is not a common event in Beckwith-Wiedemann syndrome. Ann Genet 1988;31:216-220.

54 Spritz RA, Mager D, Pauli RM, Laxova R: Normal dosage of the insulin and insulinlike growth factor II genes in patients with the Beckwith-Wiedemann syndrome. Am J Hum Genet 1986;39:265-273.

55 Giurgea I, Sanlaville D, Fournet JC, Sempoux C, Bellanne-Chantelot C, Touati G, Hubert L, Groos MS, Brunelle F, Rahier J, Henquin JC, Dunne MJ, Jaubert F, Robert JJ, Nihoul-Fekete C, Vekemans M, Junien C, de Lonlay P: Congenital hyperinsulinism and mosaic abnormalities of the ploidy. J Med Genet 2006;43:248-254. 